УДК 349.6

DOI https://doi.org/10.32849/2663-5313/2019.11.34

\title{
Христина Чопко,
}

канд. юрид. наук,

асистент кафедри соиіального права

Львівського начіонального університету імені Івана Франка

\section{ПРАВОВА ПРИРОДА ПОБУТОВИХ ВІДХОДІВ}

Стаття присвячена аналізу правового регулювання поводження з побутовими відходами в Україні. На основі дослідження наукових трактатів римських імператорів було з'ясовано, що шкідливі фактори впливу на довкілля будь-яких відходів відомі людству ще з часів римської імперії, а порядок поводження з ними був самостійним предметом дослідження в праві. Аналізуючи правову природу побутових відходів, вчені з'ясовували природу відходів як будь-яких речовин, матеріалів та предметів, що утворилися у процесі виробничтва чи споживання і повністю або частково втратили свої споживчі властивості, не мають подальшого використання за місцем їх утворення чи виявлення, масове накопичення яких $i$ зумовлює одну з причин значного погіршення в Україні екологічної ситуаиї. Відповідно до Державного класифікатора відходів вони поділяються за джерелом походження на відходи виробниитва та відходи споживання. Державна політика України у сфері поводження з відходами грунтується на Законі України «Про основні засади (стратегіï) державної екологічної політики України на період до 2020 року», дезакріпленіосновні іриниипидержавноїполітикиу сферіповодженняз відходами. Основним нормативно-правовим документом Європейського Союзу у сфері поводження й управління відходами є Директива Європейського Парламенту та Ради про відходи. Серед запропонованих Європейським Союзом для своїх країн-учасниць пакетів заходів у сфері поводження й управління відходами вважаємо актуальним запровадити в Україні заборону вироблення одноразових виробів з пластику, оскільки відходи із такого виду матеріалу, як пластик, ніколи не переробляються $і$ залишаються на звалищах. При розкритті змісту поняття побутових відходів як одного із видів відходів споживання виявлені ключові ознаки побутових відходів, що дають можливість їх відмежовувати від інших видів відходів споживання. До вказаних ознак належать такі: джерело утворення побутових відходів, а саме життя і діяльність людини, місие їх розмішення - житлові та нежитлові будинки, а також неможливість використання побутових відходів за місцем їх накопичення. 3'ясовано окремі причини масового накопичення побутових відходів на території України, до таких відноситься, зокрема, неналежна просвітницько-виховна робота серед населення. Основною проблемою, яка виникає у сфері поводження з побутовими відходами, можна вважати відсутність будь-яких стимулів у населення до дотримання правил поводження з таким видом відходів, як побутові.

Ключові слова: відходи, види відходів, відходи виробництва, відходи споживання, побутові відходи, ознаки побутових відходів.

Постановка проблеми. Значне погіршення в країні екологічної ситуації відбувається як внаслідок техногенних аварій чи катастроф, так і через процеси, які проходять в самій природі незалежно від антропогенних дій. Такими, зокрема, є зсуви, землетруси, повені тощо. Водночас небезпеку для довкілля, для життя та здоров'я людей можуть викликати і речовини, матеріали та предмети, що утворюються в процесі людської діяльності і не мають подальшого використання, тобто відходи. Відповідно до п. 1 ст. 1 Закону України «Про відходи» відходи - це будь-які речовини, матеріали і предмети, що утворилися у процесі виробництва чи споживання, а також товари (продукція), що повністю або частково втратили свої споживчі властивості і не мають подальшого використання за місцем їх утворення чи виявлення і від яких їх власник позбу- вається, має намір або повинен позбутися шляхом утилізації чи видалення. Особливо негайного вирішення вимагають проблеми із запобігання масштабному накопиченню відходів, які виникають у результаті життя і діяльності людей, тобто проблеми накопичення побутових відходів. Накопичення останніх є на сьогодні надзвичайно стрімким, а тому заходи, пов'язані з подальшим їх видаленням чи утилізацією, стають неодмінними аспектами діяльності держави у сфері забезпечення екологічної безпеки.

Актуальність нашого дослідження зумовлюється усвідомленням Україною на сучасному етапі економічного розвитку, що відходи, в тому числі побутові, є однією із причин екологічної кризи. В Основних засадах (стратегіï) державної екологічної політики України на період до 2020 року [1] наголошується, що антропогенне і техногенне навантаження на 
довкілля в Україні у кілька разів перевищуе відповідні показники у розвинутих країнах світу. Серед основних принципів державної політики у сфері охорони довкілля - захист довкілля та здоров'я людини від негативного впливу відходів, забезпечення ощадливого використання матеріально-сировинних та енергетичних ресурсів, науково обгрунтоване узгодження екологічних, економічних та соціальних інтересів суспільства щодо утворення та використання відходів 3 метою забезпечення його сталого розвитку (ст. 5 Закону України «Про відходи»).

Питання побутових відходів на монографічному рівні не досліджувалися. Проблеми поводження з відходами розглядали у своїх роботах В.I. Андрейцев, А.П. Гетьман, Р.К. Гусєв, І. Зозуля, І.І. Каракаш, В.В. Костицький, Н. Корнякова, В.І. Лозо, Н.Р. Малишева, В.Л. Мунтян, В.В. Петров, С.С. Трофимець, В.О. Юрескул, Ю.С. Шемшученко, В.В. Ярчак та інші.

Мета статті - дослідження поняття «побутові відходи», виявлення сутнісних ознак досліджуваного поняття. Нами також запропоновано окремі пропозиції щодо вирішення проблем із стрімкого накопичення побутових відходів.

Виклад основного матеріалу. Шкідливі фактори впливу відходів були відомі людству давно, адже воно на усіх етапах свого розвитку прагнуло позбутися їх. У своїх наукових трактатах видатні стародавні лікарі Гіппократ та Авіцена (Ібн Сіна) - неодноразово зазначали, що відходи та фекалії можуть викликати забруднення води та харчових продуктів, призводити до захворювання людей. Під час правління римських імператорів Доміціана (81-96 рр. н.е.) та Веспасіана (69-79 рр. н.е.) для забезпечення належного стану міст Римської імперії була прийнята низка законів про порядок видалення відходів за їх межі [2, с. 107].

Однією 3 основних загроз сучасної цивілізації міжнародним співтовариством визнана саме небезпека відходів. Основним нормативно-правовим документом ЄC у сфері поводження й управління відходами є Директива Європейського Парламенту та Ради про відходи 75/442/EWG від 15 липня 1975 р. У вказаній Директиві визначено правові рамки управління відходами та основні принципи поводження ними.

Інформаційну підтримку у вирішенні питань $з$ державного управління відходами в Україні забезпечує Класифікатор відходів ДК 005-96, затверджений Держстандартом України. У Державному класифікаторі відходів України відходами визнається будь-яка речовина та предмети, що створюються в процесі виробництва та життєдіяльності людини або внаслідок природних і техногенних катастроф, які не мають свого подальшого призначення за місцем утворення та підлягають видаленню чи переробці з метою забезпечення захисту навколишнього природного середовища і здоров'я людей або 3 метою повторного залучення в господарську діяльність як матеріальносировинні чи енергетичні ресурси.

Характерною рисою такого підходу $€$ створення відходів у будь-яких процесах, у тому числі внаслідок природних та техногенних катастроф. Відходи визнаються фактором негативного впливу на навколишне природне середовище та здоров'я людей і підлягають видаленню з наступною їх утилізацією. На думку Н. Корнякової, таке визначення має певний недолік, тобто суперечить контексту норм чинного законодавства. Зокрема, зміст норми «видалення з метою повторного залучення у господарську діяльність як матеріально-сировинних ресурсів» $€$ рівнозначним з змістом нормі «видалення 3 метою утилізації» (ст. 1 Закону України «Про відходи») [3, с. 1-2]. Вищенаведена дефініція не зовсім коректно сформульована, оскільки термін «видалення» тлумачиться як операція, яка не призводить до утилізації, що не стосується відходів, які можуть як піддаватись утилізації, так і видаленню.

У Державному класифікаторі відходів України [4] відходи поділяються на види за галузевою ознакою, а також тут закріплюється поділ послуг, пов'язаних з відходами. Зокрема, за джерелом походження вони поділяються на відходи виробництва та відходи споживання. До відходів виробництва належать матеріали, речовини, вироби, які утворилися у процесі виробництва продукції, виконання робіт чи надання послуг та не застосовуються на певному підприємстві (організації) або які повністю чи частково втратили свої споживчі властивості. Відходи споживання містять у собі вироби, матеріали, речовини, які втратили повністю або частково свої споживчі властивості у процесі масового чи особистого споживання.

Різновидом відходів споживання, проблеми із стрімким накопиченням, а також із знищенням і утилізацією яких набувають сьогодні особливої актуальності, є побутові відходи. Побутові відходи - це відходи, що утворюються в процесі життя і діяльності людини в житлових та нежитлових будинках (тверді, великогабаритні, ремонтні, рідкі), крім відходів, пов'язаних з виробничою діяльністю підприємств, що не використовуються за місцем їх накопичення 
(п. 23 ст. 1 Закон України «Про відходи» [5]). Таким чином, законодавчо закріплене визначення поняття «побутові відходи» пов'язує виникнення такого виду відходів виключно зі сферою людської діяльності Сам термін «побут» тлумачиться як позавиробнича сфера діяльності людей, пов'язана 3 задоволенням ними їхніх матеріальних та культурних потреб (житло, одяг, їжа, відпочинок тощо) [6]. Отже, назва «побутові відходи» зумовлена джерелом походження такого виду відходів, тобто це такі відходи, що утворюються в процесі життя і діяльності людини, тому однією з характерних ознак побутових відходів $є$ джерело їх утворення.

Зв'язок предмета, речовини чи матеріалу із життям і діяльністю людини є не єдиною ознакою для віднесення відходів до побутових. Серед підстав для віднесення відходів до такого виду, як побутові, є і місце їх розміщення, тобто житлові та нежитлові будинки. Не лише поява відходів в процесі життедіяльності людини, але й розміщення їх на території житлових та нежитлових будинків підтверджує приналежність предметів чи матеріалів, що утворилися в процесі життєдіяльності людей, до побутових відходів.

Однак не усі речовини, матеріали або ж предмети, що утворюються в процесі життя і діяльності людини в житлових та нежитлових будинках, набувають статусу побутових відходів. Неможливість використання відходів за місцем накопичення, їх непридатний стан $є$ наступною характерною ознакою побутових відходів. Проте відсутність можливості використання відходів повинна бути виключно у місці їх накопичення.

Таким чином, до ключових ознак побутових відходів, які дозволяють їх виокремити серед інших видів відходів споживання, належать такі: зв'язок предмета, речовини чи матеріалу із життям і діяльністю людини; місцем розміщення таких відходів є житлові та нежитлові будинки; неможливість використання за місцем їх накопичення.

Залежно від критерію класифікації побутові відходи поділяються на декілька видів. Зокрема, за агрегатним станом побутові відходи поділяють на тверді, рідкі; за об'ємом - великогабаритні, малогабаритні; за рівнем шкоди для населення - безпечні, небезпечні; за сферою утворення - сільськогосподарські, будівельні (ремонтні), садоводачного масиву, інші; за сферою надання послуг - медичної сфери, пансіонатної сфери, готельно-ресторанного бізнесу, військові; за джерелом утворення - від житлових будинків (багатоповерхових будинків та приватного сектору), будинків адміністративного призначення.
Співвідношення між накопиченням побутових відходів та заходів із їх знешкодження не співмірне. Це призводить до поглиблення екологічної кризи та загострення соціальноекономічної ситуації в державі. Виникнення такої проблеми зумовлене наявністю такого фактору, як науково-технічний прогрес, який зумовлює використання у повсякденному житті таких предметів, утилізація або видалення яких вимагає додаткового часу та ресурсів. Прикладом цього є пластик, який становить десяту частину відходів. Більшість видів пластику ніколи не переробляється, залишаючись на звалищах. Близько половини пластикових виробів одноразові. Саме тому ЄC запропонував для своїх країн-учасниць пакет заходів, покликаний на законодавчому рівні заборонити низку одноразових пластикових виробів (столові прилади, посуд, трубочки, пластикові кріплення для повітряних кульок, ватні палички та інші). Всі вироби пропонують замінити альтернативою 3 екологічно чистого матеріалу. Вказані заходи варто запозичити і Україні. У такий спосіб зменшиться рівень забруднення довкілля пластиковими відходами, що нині $є$ надзвичайно масштабним. Такий комплекс заходів дозволить знизити викиди вуглекислого газу в атмосферне повітря, скоротити збиток, завданий довкіллю. Зазначені обставини і зумовлюють величезний розрив між прогресуючим накопиченням побутових відходів та заходів з їх утилізації, що призводить до поглиблення екологічної кризи в Україні та вжиття державою додаткових заходів щодо поводження з побутовими відходами.

Що стосується причин масового забруднення довкілля відходами, в тому числі побутовими, то варто погодитись із І. Зозулею [7, с. 98], який вважає, що саме відсутність належної просвітницько-виховної роботи серед населення і є основною причиною масштабного забруднення довкілля. Для вирішення проблем із масового накопичення як відходів загалом, так і побутових недостатньо створювати додаткові сортувальні станції, окільки сортувальні станції не дадуть позитивних результатів та не будуть економічно прибутковими, доки саме населення не почне дотримуватися правил сортування відходів. Як зазначають 3 цього приводу А.П. Гетьман та В.І. Лозо [8, с. 144], серед причин виникнення проблем у сфері поводження з відходами є не лише застарілі, ресурсовитратні та забруднюючі виробничі технології, але й відсутність будь-яких стимулів для населення за відповідальне ставлення до навколишнього природного середовища. Як такі стимули можна запропонувати фінансування коштом місцевого 
бюджету додаткових заходів з благоустрою відповідного району міста у разі дотримання його мешканцями правил сортування побутових відходів, відсутність хаотичного розміщення на їх прибудинковій території побутових відходів. Крім цього, не завадило $б$ проведення і самими органами місцевого самоврядування просвітницьких заходів щодо поводження з побутовими відходами у садках, школах. У такий спосіб можна виховувати відповідальне ставлення до поводження з побутовими відходами з дитячого віку.

\section{Висновки}

Таким чином, надзвичайно актуальною на сьогодні як для України, так і для світового співтовариства є проблема стрімкого накопичення побутових відходів. Це зумовлено природою утворення такого виду відходів, місцем їх розміщення і неможливістю використання за місцем накопичення. Водночас безперервне утворення побутових відходів відбувається не лише через джерело їх накопичення, оскільки саме життєдіяльність людини і зумовлює їх виникнення, але й через недотримання самим населенням правил сортування побутових відходів, унаслідок чого лише частина побутових відходів потрапляє на сміттєсортувальну станцію та підлягає переробці.

\section{Список використаних джерел:}

1. Ярчак В.В. Історичні та правові засади поводження з побутовими відходами. Науковий вісник Університету «Львівський Ставропігіон». Серія «Юридична». Львів. 2008. Вип. І. С. 107-116.

2. Про Основні засади (стратегії) державної екологічної політики України на період до 2020 року : Закон України від 21 грудня 2010 р. № 2818-VI / Верховна Рада Украйни. Офімійний вісник України. 2011. № 3. Ст. 158.

3. Корнякова Н. Поняття відходів за законодавством України та Європейського Союзу: порівняльно-правовий аналіз. Право Україн. 2004. № 5. С. $1-4$.

4. Державний класифікатор відходів України : Наказ Держстандарту України від 29 лютого 1996 № 89. URL:https://zakon.rada.gov.ua/rada/ show/v0089217-96.

5. Про відходи : Закон України від 5 березня 1998 № 187/98-ВР / Верховна Рада України. Відомості Верхової Ради України. 1998. № 36. Ст. 242.

6. Що таке «побут»? Вікіпедія : Вільна енциклопедія. URL: http://https://uk.wikipedia.org/ wiki/\%D0\%9F\%D0\%BE\%D0\%B1\%D1\%83\%D1\%82.

7. Зозуля I. Проблеми з відходами на українсько-польських прикордонних територіях. Екологія. Право. Людина. 2013 № 19-20 (59-60). С. $97-100$.

8. Гетьман А.П., Лозо В.И. Правовые проблемы экологической политики Европейского Союза и Украины : монография. Харьков : Право, 2014. $280 \mathrm{c}$.

The article is devoted to the analysis of the legal regulation of household waste management in Ukraine. Based on a study of the scientific treatises of the Roman emperors, it was found that the harmful effects on the environment of any waste known to mankind since the Roman Empire, and the treatment of them was an independent subject of study in law. Analyzing the legal nature of household waste, the nature of waste, as any substance, material and object that has been generated in the process of production or consumption and has completely or partially lost its consumer properties, has no further use at the place of their generation or discovery, and the mass accumulation of which causes one of the reasons for the significant deterioration of the environmental situation in Ukraine. According to the National Waste Classifier, waste is divided by source of origin into production waste and consumer waste. The state policy of Ukraine in the field of waste management is based on the Law of Ukraine "On the basic principles (strategies) of the state environmental policy of Ukraine for the period up to 2020", which sets out the basic principles of state policy in the field of waste management. The European Parliament's and the Council's Waste Directive is the main legal instrument of the European Union in the field of waste management and management. Among the measures proposed in the European Union for waste management and management packages for its member countries, which is also relevant in Ukraine, is the ban on the production of disposable plastic products, as waste from such material as plastic is never recycled and thus remains in landfills. In disclosing the content of the concept of "household waste" as a type of consumer waste, identified key features of household waste that enable them to be distinguished from other types of consumer waste. These features include: the source of household waste generation, namely human life and activity, their location - residential and non-residential buildings, and the inability to use household waste at the point of accumulation. The specific reasons for the massive accumulation of household waste in the territory of Ukraine have been clarified, such as, in particular, inadequate educational work among the population. One of the main problems that arise in the sphere of municipal waste management in Ukraine is the lack of any incentives for the population to comply with the rules of waste management for this type of household waste.

Key words: waste, types of waste, production waste, waste of consumption, household waste, signs of household waste. 